\title{
SENI URUTAN TRADISIONAL MELAYU: KEARIFAN TEMPATAN YANG KEKAL RELEVAN ATAU DIPINGGIRKAN?
}

\author{
(THE ART OF MALAY TRADITIONAL MASSAGE: IS LOCAL WISDOM \\ REMAIN RELEVANT OR ALIENATED?)
}

\author{
Mohd. Fathul Khair Mohd. Dahlan \\ fakhaimd@gmail.com
}

Mardian Shah Omar

mardianso@um.edu.my

Universiti Malaya, Kuala Lumpur

Malaysia

Received: 8 Mac 2021 2020; Accepted: 12 April 2021

\begin{abstract}
The art of traditional Malay massage is one element of local wisdom that should be given more attention. Various external influences increasingly taint such massages in Malaysia and to some extent changed the art itself. This study, therefore, aimed to identify the local community's acceptance of traditional Malay massage and their openness in embracing local arts. The study also sought the public view on the future of traditional Malay massage. The paper, supported by the concept of human nature by Rousseau (1967), also collected responses from 200 respondents of various backgrounds through the distribution of online questionnaires. The study found that the traditional arts still have a place amongst the Malay community. Besides, it was proven that elements of external influences had been observed in traditional Malay massage. The implications of the study indicate that a concerted effort needs to be made to preserve this heritage art in order for it to remain relevant and produce more practitioners.
\end{abstract}

Keywords: local wisdom, arts of traditional Malay massage, massage, concept of human nature. 


\begin{abstract}
Abstrak
Seni urutan tradisional Melayu merupakan salah satu elemen kearifan tempatan yang wajar diberi perhatian. Seni urut di negara ini, kini kian dicemari oleh seni urut dari luar dan sedikit sebanyak telah mempengaruhi seni urut tempatan. Kajian ini bertujuan untuk mengenal pasti penerimaan masyarakat tempatan terhadap seni urutan tradisional Melayu, mengenal pasti sejauh mana keterbukaan masyarakat terhadap seni tempatan. Kajian ini turut mendapatkan pandangan masyarakat terhadap masa depan seni urutan tradisional Melayu. Dengan penerapan konsep tabii manusia oleh Rousseau (1967), pengkaji menggunakan kaedah soal selidik untuk mendapatkan maklum balas responden yang terdiri daripada 200 orang awam daripada pelbagai latar belakang. Soal selidik disebarkan melalui pendekatan dalam talian. Hasil kajian mendapati seni urut tradisional masih mendapat tempat dalam kalangan masyarakat Melayu. Selain itu, kajian ini mendapati memang sudah terdapat elemen-elemen pengaruh luar dalam seni urutan tradisional Melayu ini. Implikasi kajian menunjukkan bahawa satu usaha yang jitu perlu dilakukan demi melestari dan memelihara warisan ini agar kekal relevan dan memilik pewarisnya.
\end{abstract}

Kata kunci: kearifan tempatan, seni urutan tradisional Melayu, urutan, konsep tabii manusia.

\title{
Pendahuluan
}

Sejarah tamadun dunia menyaksikan perkembangan sesuatu ilmu berlaku kerana keperluan masyarakat setempat. Dalam konteks tamadun Islam dan Melayu, misalnya perkembangan ilmu perubatan berkembang seiring dengan kewujudan manusia kerana manusia itu sendiri mengalami pelbagai penyakit sekali gus memerlukan ubat-ubatan. Hal ini juga bagi memenuhi keperluan manusia untuk kekal sihat bagi membolehkan mereka menunaikan tanggungjawab kepada pencipta-Nya.

Setiap masyarakat yang mendiami muka bumi ini mempunyai ketamadunan dan peradaban keilmuan serta khazanah cendekia yang unik dan tersendiri. Hal tersebut berkembang dengan pesatnya sejajar dengan usaha yang digembleng oleh para cendekiawan tempatan yang membentuk dan mengadun pemusatan ilmu dalam kalangan masyarakatnya. Dalam konteks ketamadunan dan kebudayaan, masyarakat Melayu mengalami proses perkembangan peradaban sebermulanya dari zaman prakedatangan Islam sehinggalah penerajuan era globalisasi. Perkembangan yang positif ini telah membina satu sinergi antara anggota masyarakat yang menjadi rujukan pada ilmuwan luar di sana.

Perubatan tradisional Melayu juga tidak terlepas daripada menerima penyerapan elemen keislaman. Sebelum kedatangan Islam, perubatan Melayu ada kaitan dengan kepercayaan yang menjadi pegangan mereka. Kedatangan Hindu-Buddha ke alam Melayu, misalnya turut mempengaruhi pemikiran perubatan Melayu sehingga wujudnya penggunaan mantera. Rantau alam Melayu ini bukan setakat dicirikan sebagai kawasan yang memiliki hasil bumi yang berharga, tetapi juga sebagai kawasan yang memiliki keunikan dari segi kearifan tempatan yang membezakannya dengan kawasan masyarakat dunia yang lain. Masyarakat Melayu sememangnya terkenal dengan kepelbagaian kesenian, kebudayaan, kepercayaan, keintelektualan dan kemahiran yang tidak dimiliki oleh bangsa-bangsa lain. 
Antara keunikan masyarakat Melayu ialah kearifan tempatan dalam terapi seni urutannya. Che Noriah et al. (2012) menyatakan terapi urutan tradisional Melayu adalah antara kaedah perubatan tradisional Melayu yang berasaskan keilmuan dan pengamalan merangkumi kebudayaan Melayu dalam segenap aspek kesihatan dan pemulihan kesihatan yang diwariskan. Para pengkaji berpendapat seni urutan Melayu ini berkembang melalui pewarisan secara turun-temurun dalam kalangan ahli keluarga, penyebaran secara lisan atau secara bertulis. Kearifan tempatan yang merujuk kepada terapi urutan Melayu ini adalah dalam bentuk kaedah, penggunaan bahan, keilmuan dan falsafah yang terkandung dalam urutan tersebut.

Seni urutan tradisional Melayu ini dilihat semakin bercampuk aduk dengan pengaruh-pengaruh luar dengan kedatangan orang asing yang kini banyak mengambil alih aktiviti seni urutan ini. Kedatangan pengaruh luar yang merancakkan aktiviti urutan ini sedikit sebanyak menggugat perkembangan seni urutan tradisional Melayu (Wan Noor Hayati, 2015 \& Fatin Farhana Japre, 2017). Rentetan daripada situasi ini, wujudnya pelbagai premis asing yang menawarkan khidmat seni urutan dan kesannya memudahkan masyarakat untuk mendapatkan khidmat ururan disebabkan oleh lambakan premis urut terutamanya di kawasan bandar.

Terdapat ramai pengkaji yang telah melaksanakan kajian tentang urutan tradisional ini, antaranya Abdul Ghani et al. (2009), Abdul Rani et al. (2015), Che Noriah et al. (2012), Che Noriah et al. (2013), Fariza Fazil et al. (2012), Haniza et al. (2010), Faizal Musa (2014), Norizan et al. (2018), Rosliza dan Suriani (2017) dan Wan Farzana et al. (2017). Namun demikian, kajian-kajian ini hanya menyentuh aspek keberkesanan, jenis urutan dan bahan-bahan yang digunakan, tetapi tidak memfokuskan kepada aspek penerimaan, nilai komersial dan kerjaya tukang urut itu sendiri. Selain itu, permasalahan yang timbul adalah pengetahuan, kepakaran dan kemahiran pengamal urutan tradisional Melayu ini tidak diusahakan secara serius untuk dimajukan dan dikembangkan. Hal ini menjadi antara punca dan sebab keilmuan dan kepakaran urutan tradisional Melayu ini agak sukar untuk diperoleh disebabkan kurangnya generasi muda yang mewarisi kepakaran ini.

Oleh hal yang demikian, kajian ini bertujuan untuk mengenal pasti penerimaan masyarakat tempatan terhadap seni urutan tradisional Melayu secara keseluruhannya dan tidak hanya berfokuskan kepada satu-satu jenis urutan. Selain itu, kajian ini turut mengenal pasti sejauh mana keterbukaan masyarakat terhadap seni urutan ini. Kajian ini juga mengambil kira pandangan masyarakat terhadap masa depan seni urutan tradisional Melayu.

\section{Sorotan Kajian}

\section{Konsep Kearifan Tempatan}

Kearifan tempatan merujuk kepada kebijaksanaan cerdik pandai dalam lingkungan setempat sama ada peringkat kampung, daerah mahupun kawasan yang luas seperti negeri atau serantau. Suswandari (2017) menyatakan bahawa kearifan tempatan mengandungi tatanilai, etika, norma, aturan dan keterampilan sesuatu komuniti dalam memenuhi cabaran keberlangsungan hidupnya.

Mohd. Anuar Ramli (2018) menyatakan bahawa kearifan tempatan sebagai kebijaksanaan cerdik pandai setempat dalam menformulasikan solusi dan strategi untuk kepentingan kelangsungan sesebuah masyarakat dalam pelbagai aspek kehidupan sama ada ilmu pengetahuan, teknologi, 
bahasa, sosial, ekonomi, kesenian dan keagamaan sama ada dalam bentuk eksplisit atau implisit.

Selain itu, Mungmachon (2012) merumuskan kearifan tempatan sebagai pengetahuan asas yang diperoleh daripada keseimbangan hidup dengan alam dan hal tersebut berkaitan dengan budaya dalam sesebuah masyarakat yang bersifat terkumpul dan diturunkan daripada satu generasi kepada generasi yang lain. Dalam konteks ini, dapat disimpulkan bahawa sumber kearifan tempatan dalam seni urutan tradisional Melayu adalah daripada kitab-kitab perubatan atau manuskripmanuskrip Melayu lama yang dikarang oleh ulama dan cendekiawan Melayu dahulu seperti Kitab Bustan al-Salatin dan Hikayat Nurul Lisan Menjawab Masalah (Mohd. Faizal Musa, 2014 \& Mohd. Qayyum et al., 2020).

\section{Konsep Urutan}

Rawatan pengurutan merupakan teknik kuno yang digunakan manusia untuk mengusir kepenatan dan menyembuhkan berbagai-bagai jenis penyakit. Dalam Kamus Dewan Perdana (2020), urut ditakrifkan sebagai membiarkan badan atau bahagian badan digosok, ditekan atau dipicit untuk menghilangkan atau mengurangkan kesakitan di bahagian anggota badan. Rosnani Ripin (2016) pula menyatakan urutan sebagai satu usaha penyembuhan yang selamat, efektif dan tanpa kesan sampingan serta boleh dilakukan sendiri mahupun dengan bantuan orang yang sudah pakar atau dikenali juga sebagai tukang urut.

Reisslan dan Burghart (1987) dalam kajian mereka terhadap keberkesanan urutan kepada perkembangan dan kesihatan kanak-kanak, menyatakan bahawa urut 'berfungsi' dengan menanamkan rasa tidak takut, menguatkan struktur tulang, meningkatkan kepuasan dalam pergerakan dan membantu meningkatkan koordinasi anggota badan dan meningkatkan berat badan. Kajian Reissland dan Burghart ini lebih berfokus kepada rawatan yang digunakan oleh wanita pascabersalin dan menemukan keberhasilan teknik rawatan urutan selepas bersalin ini mampu membantu perkembangan kesihatan ibu dan juga bayi yang dilahirkan.

Cambron et al. (2007) berpandangan bahawa urutan sangat terkenal dalam konteks disiplin perubatan alternatif dan komplementari dan rawatan jenis ini sentiasa mendapat tempat dan terus berkembang mengikut peredaran zaman. Walaupun dunia masa kini sudah mempunyai perubatan moden yang dilengkapi dengan peralatan yang serba canggih dan diikuti pula dengan kepakaran para pengamal perubatan, masyarakat dunia tidak teragak-agak untuk memilih rawatan urutan bagi memulihkan kesakitan pada otot atau tulang yang mereka alami.

Ernst (2003) dan Abdul Rani et al. (2015) berpandangan bahawa urut boleh didefinisikan sebagai manipulasi tisu lembut badan yang bersistematik dengan tujuan untuk pengurangan kesakitan atau tujuan terapi lain seterusnya meningkatkan tahap kesihatan seseorang. Urutan yang dimaksudkan adalah daripada aktiviti menggosok, memicit dan menekan dengan tekanan tertentu mengikut tahap kesakitan pesakit.

\section{Konsep Urutan Tradisional Melayu}

Apabila mengulas tentang urutan tradisional Melayu, hal tersebut tidak akan jauh berbeza dengan pandangan para pengkaji terhadap keberkesanan urutan dalam teknik perawatan kesakitan yang berkaitan dengan otot ataupun tulang. Fariza Fadzil et al. (2010) antara yang mengungkap bahawa urut Melayu ialah urutan tradisional Melayu yang melibatkan manipulasi tisu lembut seluruh badan serta kesesuaiannya dalam pelbagai jenis keadaan dan penyakit. 
Urutan tradisional Melayu merupakan antara kaedah perubatan tradisional Melayu yang menyeragamkan pengetahuan dan pengamalan terhadap budaya Melayu yang meliputi aspek penjagaan kesihatan dan kaedah penyembuhan dengan turun-temurun (Che Noriah et al., 2012). Pengamalan ini lazimnya berlaku secara pewarisan tradisi dalam kalangan keluarga sama ada secara verbal atau bertulis. Menurut Abdul Ghani et al. (2009), urut Melayu ialah teknik urutan yang menggabungkan teknik ulian, membelai, melulur dan menekan tubuh seseorang dengan tangan serta menggunakan bahan berupa minyak untuk memudahkan proses urutan.

Aznim Ruhana (2017) menyatakan bahawa urutan tradisional Melayu ini mempunyai dua prinsip utama yang perlu difahami dan dikuasai oleh semua orang tukang urut, iaitu berkaitan dengan angin dan urat. Kedua-dua prinsip ini penting kerana melibatkan sistem saraf manusia bagi melegakan kesakitan dan lenguh-lenguh pada tubuh seseorang. Pandangan ini turut dinyatakan oleh Wan Farzana et al. (2017) yang menyebut urutan tradisional Melayu ini terbahagi kepada beberapa bahagian termasuklah urutan merehatkan badan, urutan penyegaran badan dan urutan melancarkan peredaran darah.

Urutan tradisional Melayu dilihat mempunyai perbezaan yang ketara dengan urutan-urutan lain. Perbezaan tersebut merujuk kepada kajian Rosnani Ripin (2016) yang menjelaskan etika urut Melayu yang sifatnya mematuhi tuntutan syariah. Etika tersebut mesti dipatuhi oleh pengamal urutan tradisional Melayu yang mempunyai ciri-ciri seperti beragama Islam, tidak melakukan perkara-perkara yang boleh membawa kepada syirik, ikhlas dalam mengerjakan sesuatu semata-mata kerana Allah dan ketahanan jiwa dan rohani.

Pandangan dan kajian oleh Rosnani Ripin yang menyatakan bahawa seorang tukang urut tidak boleh melanggar pantang larang seperti melakukan maksiat, mengharapkan ganjaran dan balasan oleh orang lain, menyimpan sifat dendam terhadap orang lain dan tidak berasa bangga dan hebat dengan kepakaran yang dimiliki oleh tukang urut itu. Dalam dapatan kajian yang lain, Haniza Mohd. Anuar et al. (2010) menyebut bahawa etika dalam urutan tradisional Melayu ini merujuk kepada tukang urut dan pelanggannya. Menurut Haniza Moh. Anuar, seorang tukang urut hanya boleh menjalankan sesi urutan terhadap pelanggan yang sama jantina dengannya.

\section{Metodologi Kajian}

Kajian ini mengaplikasikan tinjauan deskriptif dengan menggunakan kaedah instrumen soal selidik yang diedarkan oleh penyelidik secara rawak kepada masyarakat. Pengedaran soal selidik ini adalah dengan menggunakan kaedah dalam talian menerusi penyebaran maklumat melalui aplikasi Whatsapp dan Facebook. Kajian tinjauan deskriptif adalah satu kajian terhadap perkara yang sedang berlaku. Keadaan ini melibatkan pengumpulan data, membuat interpretasi, perbandingan dan merumus generalisasi atau kesimpulan secara umum. 


\section{Populasi dan Pensampelan}

Dalam kajian ini, keseluruhan sampel adalah daripada pelbagai latar belakang demografi yang dikawal oleh pengkaji menggunakan instumen soal selidik. Pengkaji memilih 450 orang dalam lingkungan populasi sasaran yang mengandungi semua unsur yang hendak dikaji dan boleh diperoleh (Fuad, 2017). Mengikut jadual Kreije dan Morgan (1970), sampel kajian perlu mewakili populasi. Sampel yang digunakan seramai 200 orang dan kesemuanya dipilih dalam kalangan populasi yang terdiri daripada 450 orang awam.

\section{Instrumen Kajian}

Pengkaji menggunakan kaedah soal selidik dan disebarluaskan kepada orang awam untuk mendapatkan data kajian yang dijalankan. Kajian dalam bentuk soal selidik kerap digunakan dalam kajian lapangan kerana meliputi semua aspek yang diperlukan oleh seseorang pengkaji. Penggunaan soal selidik dalam pemerolehan data kajian merupakan cara yang paling mudah untuk mengumpul dan merekodkan data daripada ratusan dan ribuan responden (Munn \& Drever, 1990). Melalui kaedah soal selidik ini juga, segala butiran peribadi mengenai responden disimpan dengan rapi. Hal ini membolehkan responden menjawab soalan-soalan yang terdapat dalam soal selidik yang disediakan dengan tanpa resah dan curiga. Pengkaji membina instrumen soal selidik menggunakan kombinasi soalan, iaitu pendekatan soalan respons terbuka dan soalan respons terhad. Tujuan pengkaji menggunakan soalan respons terbuka adalah untuk membenarkan responden memberikan pandangan dan saranan tanpa dipengaruhi oleh pengkaji (McGuirk \& O'Neill, 2016 \& Reja et al., 2003). Soalan respons terhad pula, pengkaji membahagikannya kepada dua bahagian, iaitu bahagian demografi responden dan soal selidik tentang urutan tradisional Melayu yang dilakukan secara rawak. Kajian ini menggunakan lima skala Likert (L), iaitu 1 (L1), = sangat tidak setuju, 2 $(\mathrm{L} 2)=$ tidak setuju, 3 (L3) = tidak pasti, 4 (L4) = setuju dan 5 (L5) = sangat setuju. Soalan-soalan dalam instrumen soal selidik pula ditandai dengan petunjuk seperti soalan 1 (S1), soalan 2 (S2), soalan 3 (S3), soalan 4 (S4) dan soalan 5 (S5).

Pengkaji telah merekodkan setiap set soal selidik yang telah dilengkapkan oleh reponden melalui Google Form untuk dianalisis. Pengkaji telah menetapkan seramai 200 orang responden untuk menjawab soal selidik berdasarkan jadual Krejcie dan Morgan (1970). Setiap item soal selidik dianalisis dalam aplikasi Statistical Package for the Social Sciences (SPSS) versi 26. Semua maklumat dan data diklasifikasikan dengan kod-kod yang tertentu oleh pengkaji dan dianalisis mengikut objektif kajian. Statistik deskriptif boleh dilihat dalam paparan data demografi responden seperti jantina, umur dan kekerapan mendapatkan urutan setiap responden yang akan dianalisis secara deskriptif. Analisis data deskriptif menggunakan data jenis kekerapan dan nilai peratusan.

\section{Kerangka Konsep Kajian}

Penyelidikan ini menggunakan konsep tabii manusia yang dipelopori oleh Jean-Jasques Rousseau (1967) dalam meninjau kekerapan masyarakat di Malaysia mendapatkan khidmat urutan tradisional Melayu dan pandangan mereka terhadap seni urutan ini. Pendekatan konsep tabii manusia ini diterapkan setelah pengkaji melihat taburan kekerapan responden mendapatkan urutan untuk tu- 
juan melegakan kesakitan yang mereka alami. Merujuk Rousseau (1967), tabii manusia yang pada asalnya ialah ciptaan Tuhan telah mengalami perubahan akibat pengaruh persekitaran dan kemajuan materialisme. Rousseau berpandangan manusia dilahirkan dalam keadaan sifatnya yang baik. Rousseau juga mengemukakan dua pandangan tentang tabii manusia, iaitu kebebasan memilih dan kemampuan manusia untuk penambahbaikan. Namun demikian, pengkaji mengambil aspek kebebasan memilih sebagai fokus dalam penyelidikan ini.

Dalam konteks kajian ini, pengkaji meneliti aspek kebebasan memilih dalam kalangan masyarakat (responden) untuk mendapatkan rawatan terhadap penyakit yang mereka alami sama ada ke arah perawatan alternatif seperti urutan atau perubatan moden. Dengan penerapan konsep tabii manusia dalam penyelidikan ini, pengkaji dapat mengaitkannya dengan kecenderungan masyarakat untuk mendapatkan urutan tradisional Melayu sekiranya mereka mengalami kesakitan di bahagian tubuh dan sebagai langkah untuk melegakannya.

\section{Dapatan Data}

Jadual 1.0 ialah dapatan data mengenai maklumat latar belakang responden, manakala jadual 2.0 hingga Jadual 6.0 merupakan jadual pemetaan dapatan maklum balas daripada responden yang memenuhi piawai soal selidik yang menggunakan skala Likert. Jadual 2.0 ialah jadual tentang maklum balas responden terhadap kekerapan berurut. Jadual 3.0 pula menunjukkan maklum balas responden terhadap penerimaan seni urutan tradisional Melayu. Seterusnya, jadual 4.0 adalah tentang maklum balas responden terhadap pengaruh luar dalam urutan tradisional Melayu diikuti pula dengan jadual 5.0 yang mencirikan maklum balas responden terhadap kerjaya urutan tradisional Melayu. Jadual 6.0 ialah maklum balas responden terhadap urutan tradisional Melayu dan nilai komersial.

Selain penggunaan skala Likert dalam soal selidik, pengkaji juga menggunakan pendekatan soalan respons terbuka yang menggalakkan responden menyatakan pendapat dan pandangan terhadap seni urutan tradisional Melayu di Malaysia. Pengkaji mendapati bahawa responden memberikan galakan yang positif dan bernas terhadap seni urutan tradisional Melayu dan hal ini dijelaskan pada bahagian perbincangan.

Jadual 1.0: Jantina Responden

\begin{tabular}{|c|c|c|c|c|c|c|}
\hline \multirow{2}{*}{ Paltime } & \multicolumn{2}{|c|}{$I=P_{i}$} & \multicolumn{2}{|c|}{ Pel-ial } & \multirow{2}{*}{ flet } & \multirow{2}{*}{$\mathbf{4}$} \\
\hline & Bi? & 5 & Bi? & $\%$ & & \\
\hline Fnim & 82 & 41.0 & III & 59.0 & 200 & $17: 0$ \\
\hline
\end{tabular}

Jadual 1.0 menunjukkan dapatan data tentang latar belakang jantina responden yang terlibat dalam soal selidik ini. Data menunjukkan sebanyak 82 (41\%) orang responden mewakili lelaki, manakala 118 (59\%) orang pula mewakili responden perempuan. Hal ini menunjukkan bahawa responden perempuan lebih banyak menggunakan khidmat urutan tradisional Melayu berbanding responden lelaki. 
Merujuk kepada jadual 2.0, data menunjukkan bahawa seramai 198 orang responden pernah mendapatkan khidmat urutan dalam kehidupan mereka. Taburan data soal selidik yang diperoleh menunjukkan seramai 28 orang responden (14\%) menyatakan kerap mendapatkan urutan tradisional, 65 orang $(32.5 \%)$ pula menyatakan sesekali sahaja dan 96 orang responden (48\%) memilih jarang berurut. Seramai 9 orang responden (4.5\%) menyatakan mereka mendapatkan urutan hanya sekali seumur hidup sahaja. Dapatan data juga menunjukkan seramai 2 orang responden (1\%) tidak pernah mendapatkan apa-apa urutan seumur hidup mereka. Berdasarkan data yang ditunjukkan dalam jadual 2.0, hal ini bermaksud orang awam masih mencari khidmat urutan walaupun perubatan moden sudah berkembang pesat pada zaman kini.

Jadual 2.0: Maklum Balas Responden Terhadap Kekerapan Berurut

\begin{tabular}{|c|c|c|}
\hline Futh & E7n= & Prth ( \\
\hline Farp & 2I & 14D \\
\hline Soretili & $\mathbf{6}$ & 32.5 \\
\hline InIn & $\mathbf{9 6}$ & 480 \\
\hline 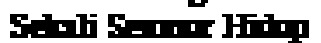 & 9 & 45 \\
\hline TH:hle Pa:h & $\mathbf{z}$ & 1.0 \\
\hline Jing & 200 & 15u \\
\hline
\end{tabular}

Berdasarkan analisis hasil soal selidik, pengkaji telah mengkategorikan dapatan kajian ini kepada empat aspek, iaitu penerimaan, pengaruh luar, pandangan terhadap kerjaya tukang urut dan nilai komersial. Kesemua aspek ini diterjemahkan dalam bentuk jadual dan disertakan dengan peratusan.

Jadual skala Likert 3.0 di bawah menunjukkan data maklum balas responden bagi keseluruhan aspek penerimaan responden terhadap seni urutan tradisional Melayu. Data yang berikutnya menunjukkan 89\% daripada responden bersetuju dan sangat bersetuju menyatakan mereka mengetahui kebaikan yang terkandung dalam seni urutan tradisional Melayu ini yang mewakili soalan 1 (S1) dalam senarai soal selidik. Hanya 3.5\% reponden yang tidak bersetuju dan sangat tidak bersetuju bahawa seni urutan tradisional ini tidak mempunyai kebaikan kepada diri mereka. Dalam hal ini, mereka berpendapat seni urutan tradisional Melayu ini hanya sekadar untuk mengurangkan rasa lenguh dan melegakan kesakitan sahaja berbanding perubatan moden yang lebih maju dan teruji secara klinikal keberkesanannya. Rata-rata responden yang terlibat dengan kajian ini menyatakan setuju dan sangat setuju bahawa mereka sentiasa mendapatkan khidmat urutan tradisional Melayu (S2) yang menunjukkan masyarakat masih mencari urutan tradisi ini, iaitu dengan peratusan sebanyak $62.1 \%$, manakala $21 \%$ responden menyatakan mereka tidak setuju dan sangat tidak setuju terhadap penyataan ini. 
Jadual 3.0: Maklum Balas Responden Terhadap Penerimaan tentang Seni Urutan Tradisional Melayu

\begin{tabular}{|c|c|c|c|c|c|c|c|c|c|c|c|c|}
\hline \multirow{3}{*}{ Sering } & \multicolumn{10}{|c|}{ 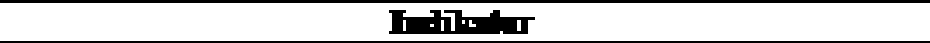 } & \multirow{3}{*}{ Jill } & \multirow{3}{*}{$\mathbf{T H}$} \\
\hline & \multicolumn{2}{|c|}{$\mathbf{L 1}$} & \multicolumn{2}{|c|}{$\mathbf{I 2}$} & \multicolumn{2}{|c|}{ L3 } & \multicolumn{2}{|c|}{$\mathbf{L}$} & \multicolumn{2}{|c|}{ L5 } & & \\
\hline & 直 & $\pi$ & F匀 & $\bar{x}$ & 角 & $\boldsymbol{x}$ & Eה & $\mathbf{X}$ & Bi & $\mathbf{x}$ & & \\
\hline S1 & $\mathbf{3}$ & 15 & 4 & 20 & 15 & 75 & $\mathbf{8 3}$ & 415 & 95 & 475 & & \\
\hline $\mathbf{s}$ & 5 & 3. & 36 & 180 & 32 & 15.0 & $\boldsymbol{3}$ & 365 & 53 & 266 & & \\
\hline $\mathbf{s}$ & 7 & 35 & 5 & 3. D & 36 & 110 & 94 & 57 & 57 & 25 & 20 & 1 15e \\
\hline $\mathbf{S 4}$ & 118 & 90 & 47 & 235 & $\mathbf{2 2}$ & 11.0 & 9 & 45 & 4 & 20 & & \\
\hline $\mathbf{S S}$ & 9 & 45 & 24 & 120 & 47 & 235 & 76 & 조묨 & 44 & Z20 & & \\
\hline
\end{tabular}

Responden juga menyatakan bahawa mereka berasa setuju dan sangat bersetuju untuk menyampaikan atau menguar-uarkan keberkesanan tentang urutan tradisional Melayu kepada rakan-rakan dan ahli keluarga (S3) dengan nilai peratus sebanyak 75.5\% dan selebihnya sebanyak $6.5 \%$ untuk skala sangat tidak bersetuju dan tidak bersetuju serta $18 \%$ bagi responden yang tidak pasti untuk menghebahkannya. Hal ini menunjukkan bahawa masyarakat masih berasa yakin dengan urutan tradisionl Melayu dan berasa terbuka untuk menghebahkannya kepada orang lain. Sebanyak $83.5 \%$ tidak bersetuju dan sangat tidak bersetuju bahawa mereka tidak akan mencadangkan kaedah urutan tradisional Melayu kepada orang lain (S4). Hal ini amat berkaitan dengan (S3) kerana masyarakat masih meyakini seni urutan tradisional Melayu dan diterima oleh orang ramai. Terdapat $11 \%$ responden berasa tidak pasti dan $6.5 \%$ berasa tidak bersetuju serta sangat tidak bersetuju untuk mencadangkan urutan tradisional Melayu kepada orang lain. Berdasarkan dapatan soal selidik, pengkaji mendapati bahawa orang awam berasa malu dan segan untuk berkongsi tentang pengalaman mereka ketika mendapatkan urutan. Dapatan akhir dalam aspek penerimaan responden terhadap urutan tradisional Melayu, pengkaji mendapati bahawa responden cenderung untuk membandingkan keberkesanan urutan oleh tukang-tukang urut (S5) yang pernah mereka dapatkan khidmat urutan tersebut. Data menunjukkan sebanyak 60\% responden bersetuju dan sangat bersetuju dengan penyataan dalam perkara ini. Pada masa yang sama, 23\% responden berasa tidak pasti untuk membandingkan kesan urutan tersebut dan 16.5\% menunjukkan tidak bersetuju dan sangat tidak bersetuju untuk membuat perbandingan keberkesanan urutan oleh tukang-tukang urut yang ada. Hal ini juga mungkin disebabkan oleh sesetengah tukang urut berpandangan bahawa kaedah dan teknik urutan mereka mempunyai keistimewaan yang tersendiri dan berbeza dengan tukang urut yang lain.

Pengkaji turut mendapatkan maklum balas responden terhadap pengaruh luar dalam urutan tradisional Melayu seperti yang ditunjukkan dalam Jadual 4.0 di bawah. Hampir $92.5 \%$ responden berpendapat bahawa urutan tradisional Melayu ialah seni warisan budaya asli Melayu (S1) dan berkaitan dengan indikator (S2) yang merujuk kepada urutan tradisional Melayu perlu mencampurkan seni urutan dari luar. Nilai peratusan yang dipeoleh untuk (S2) ialah $57.5 \%$ sekali gus menolak dakwaan bahawa urutan tradisional Melayu adalah daripada proses penyerapan nilai budaya daripada unsur luar. Dalam konteks pengaruh luar ini, responden memberikan maklum balas setuju dan sangat setuju bahawa urutan tradisional Melayu mesti dikekalkan identiti aslinya (S3) dengan nilai peratusan sebanyak $86.5 \%$. 
Jurnal Pengajian Melayu - JOMAS, Jilid 32(1), 2021: 138-155

Jadual 4.0: Maklum Balas Responden Terhadap Pengaruh Luar dalam Urutan Tradisional Melayu

\begin{tabular}{|c|c|c|c|c|c|c|c|c|c|c|c|c|}
\hline \multirow{3}{*}{ Saln } & \multicolumn{10}{|c|}{ עו } & \multirow{3}{*}{ J } & \multirow{3}{*}{$\mathbf{T H}$} \\
\hline & \multicolumn{2}{|c|}{ L1 } & \multicolumn{2}{|c|}{$\mathbf{L 2}$} & \multicolumn{2}{|c|}{ L_3 } & \multicolumn{2}{|c|}{ LA } & \multicolumn{2}{|c|}{ LS } & & \\
\hline & 直 & $\%$ & Bil & $\mathbf{x}$ & Bi & $\mathbf{x}$ & Bi & $\mathbf{x}$ & Bi & $\mathbf{x}$ & & \\
\hline S1 & 2 & 1.0 & 2 & 1.0 & 11 & 55 & 5 & 325 & 120 & 00 & & \\
\hline S2 & 4 & 225 & $\boldsymbol{0}$ & 300 & 50 & ED & 32 & 160 & 13 & 65 & & \\
\hline $\mathbf{s}$ & $\mathbf{3}$ & 15 & 4 & 20 & 20 & 100 & 5 & 325 & 101 & 540 & 200 & 150 \\
\hline $\mathbf{S 4}$ & 11 & 55 & $\mathbf{8 6}$ & BD & $\mathbf{1 8}$ & D.0 & 70 & 35.0 & 15 & 75 & & \\
\hline $\mathbf{S S}$ & $\mathbf{2}$ & 145 & 43 & 215 & 9 & 345 & 5] & 255 & $\mathbf{z}$ & 4.0 & & \\
\hline
\end{tabular}

Merujuk kepada (S3) yang mewakili urutan tradisional Melayu mengalami proses pencampuran seni urutan lain, dapatan data yang diperoleh menunjukkan nilai peratusan yang agak seimbang. Sebanyak $43.0 \%$ responden menyatakan tidak pasti dengan penyataan tersebut. Indikator L4 dan L5 pula menunjukkan nilai peratusan kira-kira $42.5 \%$ yang menyatakan setuju dan sangat setuju. Kedua-dua nilai ini jelas bahawa responden mempunyai pandangan dan harapan yang tersendiri terhadap seni urutan tradisional Melayu dalam mengekalkan kemandiriannya untuk generasi masa hadapan. Begitu juga dengan (S5) yang mewakili penyataan urutan tradisional Melayu wajar melalui proses perubahan dengan mencampurkan pengaruh luar. Pecahan nilai peratusan tidak begitu ketara apabila $26.0 \%$ responden memilih tidak setuju dan sangat tidak setuju, 34.5\% pula memilih tidak pasti dan $29.0 \%$ responden memilih setuju dan sangat setuju. Hal ini begitu jelas bahawa orang awam mempunyai cita rasa yang tersendiri dan pandangan peribadi terhadap seni urutan tradisional Melayu.

Data yang ditunjukkan dalam Jadual 5.0 adalah tentang maklum balas responden terhadap kerjaya urutan tradisional Melayu. Dapatan data yang diperoleh menunjukkan $65.5 \%$ responden berpandangan setuju dan sangat setuju tukang bahawa urut mesti dijadikan sebagai satu kerjaya tetap (S1) setelah pengkaji mendapati ramai responden yang terlibat dalam soal selidik ini menghadapi kesukaran untuk mencari tukang urut yang asli dalam mendapatkan khidmat urutan tradisional Melayu. Hasil kajian juga memaparkan nilai peratusan responden yang menandakan setuju dan sangat setuju untuk kerjaya tukang urut mempunyai masa depan yang cerah (S2) sebanyak $69.0 \%$. Merujuk kepada jadual 4.0, sebanyak 83.0\% responden bersetuju dan sangat setuju tentang tukang urut mesti mengajarkan seni urut kepada orang awam untuk mewariskan ilmu urutnya kepada pelapis atau generasi yang seterusnya (S3).

Jadual 5.0: Maklum Balas Responden Terhadap Kerjaya Urutan Tradisional Melayu

\begin{tabular}{|c|c|c|c|c|c|c|c|c|c|c|c|c|}
\hline \multirow{3}{*}{ Se-10 } & \multicolumn{10}{|c|}{ 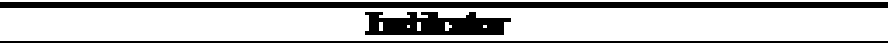 } & \multirow{3}{*}{ R. } & \multirow{3}{*}{$\mathbf{M}$} \\
\hline & \multicolumn{2}{|c|}{ LI } & \multicolumn{2}{|c|}{ L2 } & \multicolumn{2}{|c|}{ I3 } & \multicolumn{2}{|c|}{ LA } & \multicolumn{2}{|c|}{ LS } & & \\
\hline & 瓦 & $\bar{x}$ & Eill & $\mathbf{x}$ & Eה & $\bar{x}$ & $\overline{\mathbf{B}}$ & 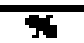 & $\overline{\mathbf{E}}$ & $\mathbf{x}$ & & \\
\hline SI & 4 & 2.0 & 16 & $\overline{10}$ & 43 & 215 & 90 & 450 & 47 & $\overline{235}$ & & \\
\hline $\mathbf{S Z}$ & 3 & 15 & 15 & 75 & 44 & ב20 & 94 & D & 44 & $\mathrm{mo}$ & & \\
\hline $\mathbf{s} 3$ & 4 & 2.0 & 4 & 2.0 & 20 & 130 & 96 & 450 & 70 & 35.0 & 200 & 1010 \\
\hline $\begin{array}{l}\text { S1 } \\
\text { S5 }\end{array}$ & $\begin{array}{l}3 \\
4\end{array}$ & $\begin{array}{l}15 \\
2.0\end{array}$ & $\begin{array}{l}3 \\
6\end{array}$ & $\begin{array}{l}15 \\
3.0\end{array}$ & $\begin{array}{l}16 \\
17\end{array}$ & $\begin{array}{l}80 \\
85\end{array}$ & 85 & $\begin{array}{l}425 \\
405\end{array}$ & $\begin{array}{l}\mathbf{9 3} \\
\mathbf{9 2}\end{array}$ & $\begin{array}{l}465 \\
460\end{array}$ & & \\
\hline
\end{tabular}


Berdasarkan dapatan data yang berikutnya, ramai responden bersetuju dan sangat setuju jika seni urutan tradisional Melayu dikomersialkan (S4) dengan nilai peratusan yang diperoleh sebanyak $89.0 \%$. Hal ini menunjukkan dengan jelasnya bahawa ramai orang awam meminati seni urutan tradisional Melayu ini. Dapatan yang terakhir dalam bahagian ini pula menunjukkan sebanyak $86.5 \%$ responden melihat urutan tradisional Melayu ini memerlukan satu penjenamaan yang lebih segar (S5). Penjenamaan ini merangkumi aspek cara pengendalian khidmat urutan trdisional Melayu seperti penyediaan ruang atau tempat urutan yang lebih kondusif dan selesa serta pendaftaran harta intelek dengan mempatenkan produk minyak urut yang dihasilkan menerusi Perbadanan Harta Intelek Malaysia (MyIPO).

Data yang ditunjukkan dalam jadual 6.0 ialah dapatan soal selidik yang menjurus kepada maklum balas reponden terhadap urutan tradisional Melayu dan nilai komersialnya. Hasil analisis data mendapati bahawa responden bersetuju dan sangat bersetuju sekiranya tukang urut mendapatkan lesen atau pengiktirafan untuk masa depan kerja dan kerjayanya (S1) yang dibuktikan dengan nilai peratusan sebanyak $88.5 \%$. Responden juga bersetuju dan sangat setuju jika tukang urut memerlukan publisiti atau hebahan tentang kepakaran yang mereka miliki (S2) yang ditandai dengan peratusan sebanyak $89.0 \%$ dan ini adalah satu kadar peratusan yang sangat positif dan menggalakkan. Rentetan daripada hal ini, nilai peratusan responden bagi skala setuju dan sangat setuju terhadap bahan yang digunakan juga perlu dikomersialkan serta didaftarkan harta inteleknya (S3), namun sebanyak $80.5 \%$ dan $14.5 \%$ responden menandakan skala tidak pasti terhadap keraguan mereka tentang sumber bahan yang digunakan sama ada diperaku oleh pihak berautoriti dan aspek kebersihannya.

Jadual 6.0: Maklum Balas Responden Terhadap Urutan Tradisional Melayu dan Nilai Komersial

\begin{tabular}{|c|c|c|c|c|c|c|c|c|c|c|c|c|}
\hline \multirow{3}{*}{ San!: } & \multicolumn{10}{|c|}{ Ifthe } & \multirow{3}{*}{ Jill } & \multirow{3}{*}{$\mathbf{T H}$} \\
\hline & \multicolumn{2}{|c|}{ II } & \multicolumn{2}{|c|}{ L2 } & \multicolumn{2}{|c|}{ L3 } & \multicolumn{2}{|c|}{ L } & \multicolumn{2}{|c|}{ LE } & & \\
\hline & E⿱一𫝀月 & $\%$ & Eill & $\%$ & E亚 & 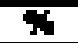 & $\overline{\mathbf{B}}$ & $\pi$ & $\overline{\text { Bi }}$ & 9 & & \\
\hline S1 & $\mathbf{3}$ & 15 & 5 & $\overline{25}$ & 15 & 75 & 67 & $\overline{335}$ & 110 & 550 & & \\
\hline $\mathbf{5} \mathbf{2}$ & $\mathbf{3}$ & 15 & $\mathbf{l}$ & 0.5 & 19 & 95 & 84 & 425 & 93 & 465 & & \\
\hline $\mathbf{5 t}$ & 2 & 1.0 & $\mathbf{8}$ & 4.0 & $\mathbf{2 0}$ & 145 & 80 & 40 & 81 & 40 & 20 & 16a \\
\hline $\begin{array}{l}\text { S4 } \\
\text { S5 }\end{array}$ & $\begin{array}{c}3 \\
116\end{array}$ & $\begin{array}{l}15 \\
\text { S10 }\end{array}$ & $\begin{array}{l}\mathbf{5} \\
\mathbf{3 9}\end{array}$ & $\begin{array}{c}75 \\
195\end{array}$ & $\begin{array}{l}\mathbf{2 5} \\
\mathbf{1}\end{array}$ & $\frac{12.5}{9.0}$ & $\begin{array}{l}76 \\
16\end{array}$ & $\frac{310}{80}$ & $\begin{array}{l}\mathbf{8 1} \\
11\end{array}$ & $\frac{405}{55}$ & & \\
\hline
\end{tabular}

Bagi (S4) pula merupakan indikator bagi keperluan tukang urut membuka premis khas untuk perkhidmatannya. Sebanyak $78.5 \%$ responden bersetuju dan sangat setuju seandainya tukang urut mempunyai sebuah premis khas seiring dengan usaha untuk mengkomersialkan seni urutan tradisional Melayu ini. Hal ini menunjukkan bahawa orang awam menerima urutan tradisional Melayu sebagai satu kaedah rawatan alternatif bagi melegakan kesakitan pada badan. Responden juga berasa tidak setuju dan sangat tidak setuju jika seni urutan tradisional Melayu ini tidak wajar dikomersialkan (S5). Indikator menunjukkan nilai peratusan sebanyak 76.5\% yang menjelaskan bahawa seni urutan tradisional Melayu ini sememangnya mempunyai nilai komersialnya yang tersendiri. 


\section{Perbincangan}

Urutan tradisional Melayu sememangnya mempunyai kelebihannya yang tersendiri dalam merawat dan memberikan kelegaan kepada pesakit. Berdasarkan urutan tradisional Melayu, pesakit yang terlibat dengan penggunaan urutan ini memperlihatkan perubahan dalam mobiliti, aktiviti dan kehidupan seharian mereka seiring dengan kualiti kehidupan dan bergantung kepada keadaan pesakit semasa mendapatkan khidmat urutan tradisional Melayu. Hal ini jelas menunjukkan bahawa masyarakat mempunyai tahap keyakinan dan masih bersifat terbuka dan menerima kaedah perawatan ini walaupun sedang berada dalam dunia era teknologi maklumat yang pesat berkembang. Hal ini disokong oleh Fariza Fadzil et al. (2012) yang menyatakan pesakit berkemungkinan memperoleh perkembangan positif apabila mereka memilih urut Melayu sebagai kaedah rawatan alternatif semasa dalam tempoh awal pesakit menghadapi angin ahmar (strok) dan pesakit perlu membuat rawatan susulan untuk mendapatkan kesan yang lebih baik.

Faktor kekurangan tukang urut Melayu yang menawarkan perkhidmatan urutan tradisi ini, turut membuka peluang kemasukan pengaruh luar seperti urutan Thai (Thai massage), urutan Bali (Balinese massage), urutan sukan (sport massage), Ayurveda, hot stone, Shiatsu, urutan refleksologi, urutan batin, urutan kiropraktik dan sebagainya yang bersekali dengan kedatangan tukang-tukang urut asing. Selain itu, banyak premis urutan telah dibuka terutamanya di kawasan bandar besar. Premis-premis urutan yang dibuka menggunakan khidmat tukang urut dari luar seperti Thailand, Indonesia, Myanmar, China dan sebagainya. Pemilik premis juga mampu menjana pendapatan yang lumayan hasil daripada urutan yang ditawarkan (Fatin Farhana Japre, 2017 \& Wan Noor Hayati, 2015). Hal ini secara tidak langsung menunjukkan seni urutan tradisional Melayu semakin tenggelam daripada pengetahuan masyarakat di negara ini disebabkan oleh lambakan tukang urut dari luar yang menawarkan urutan yang dikatakan hanya untuk kepuasan dan sensasi sahaja.

Kearifan tempatan dalam ruang lingkup Alam Melayu yang mempunyai kepelbagaiannya wajar dibanggakan oleh seluruh penduduk dan pendukungnya. Setelah kemasukan Islam ke alam Nusantara ini, sumber kearifan tempatan dalam kalangan orang Melayu lebih jernih dan bersendikan syarak dan tauhid. Menurut Rahimin Affandi et al., (2013), dalam konteks dunia global yang menyaksikan kebanyakan formula penyelesaian masalah manusia sejagat didasari dengan formula acuan Barat yang bersifat euro-centric. Merujuk kenyataan beliau, sudah tiba masanya masyarakat di Malaysia mengangkat dan memperkenalkan paradigma tersendiri dengan memartabatkan kearifan tempatan yang menjadi milik kita.

Dalam kajian ini, hasil kajian mendapati 99\% responden yang terlibat dengan kajian ini pernah mendapatkan urutan tradisional dalam kehidupan mereka walaupun sekali seumur hidup mereka. Ada juga dalam kalangan responden menyatakan bahawa mereka sukar untuk mendapatkan khidmat tukang urut yang menawarkan perkhidmatan urutan tradisional Melayu. Inilah buktinya kearifan tempatan seni urut Melayu ini kekurangan pakar ataupun ilmu yang ada tidak diwarisi ataupun dipindahkan. Kekerapan ini juga dilihat daripada perspektif kebolehdapatan khidmat tukang urut di sesebuah kawasan penempatan masyarakat. Kebanyakan tukang urut tradisional Melayu ini berada di kawasan perkampungan yang terletak jauh daripada masyarakat bandar. Selain faktor kawasan, faktor bilangan tukang urut tradisional Melayu juga amat sedikit dalam sesebuah kelompok masyarakat dan penempatan. Meskipun dalam sebuah kampung, untuk mendapatkan seorang tukang urut yang benar-benar pakar dalam bidang urutan tradisional Melayu amat sukar dicari. Oleh sebab itu, masyarakat lebih gemar mendapatkan urutan komersial seperti di spa atau premis-premis di pasar raya. 
Bersandarkan kepada konsep tabii manusia Rousseau (1967), menjadi hakikat manusia untuk mendapatkan sesuatu yang boleh memenuhi kehendak dan tujuan peribadi. Dalam konteks penyelidikan ini, responden yang mendapatkan khidmat urutan tradisional Melayu ini adalah untuk melegakan kesakitan yang mereka alami seperti sengal badan, terseliuh, membetulkan peranakan dan sebagainya. Hal ini juga bertetapan dengan kepentingannya terhadap penjagaan kesihatan diri mereka sendiri. Dalam pada masa yang sama, mereka tidak menafikan keberkesanan perubatan moden, tetapi soal ikhtiar untuk melegakan kesakitan wajar diberikan perhatian dan keutamaan.

Dapatan soal selidik yang telah dijalankan oleh pengkaji turut menunjukkan bahawa masyarakat masih menerima dan meminati seni urutan tradisional Melayu. Keterbukaan ini dilihat menerusi aspek penerimaan orang awam terhadap urutan itu sendiri. Hasil analisis soal selidik yang dilakukan membuktikan bahawa masyarakat mengetahui kebaikan yang terdapat dalam seni urutan. Secara tidak langsung mereka menjadi jurupromosi khidmat yang disediakan oleh tukang urut tradisional Melayu dengan menghebahkan kepada rakan atau sesiapa sahaja selepas menjalani sesi urutan. Responden yang terlibat juga mempunyai pengetahuan asas tentang bahan dan aspek seni yang terdapat pada tukang urut tradisional.

Berhubung dengan konsep tabii manusia, Rousseau (1967) mengatakan bahawa masyarakat Melayu cenderung untuk mendapatkan urutan tradisional Melayu sekiranya mereka mengalami kesakitan di bahagian tubuh untuk melegakannya dilihat positif dan memberangsangkan. Masyarakat semakin menerima urutan tradisional Melayu ini apabila mereka mengalami sendiri kesan dan penyembuhan hasil daripada urutan yang diterima. Hal ini turut disokong dengan kajian Che Noriah et al. (2013) yang menyatakan bahawa ramai dalam kalangan pesakit Melayu khususnya mencari urutan tradisional Melayu adalah yang berkaitan dengan penyakit mereka. Kebanyakannya mempunyai penyakit seperti tekanan darah tinggi, patah tulang akibat kemalangan, masalah tulang belakang, resdung kronik, angin pasang dan sebagainya. Pesakit akan diurut menggunakan kaedah yang tertentu bergantung kepada jenis penyakit yang dialaminya. Pada masa yang sama, tukang urut tradisional Melayu akan memulakan sesi urutan dengan membacakan ayat-ayat suci al-Quran yang khusus sebagai pendekatan yang mampu memberikan ketenangan kepada psikologi pesakit (Wan Fariza et al., 2013).

Selain itu, urutan tradisional Melayu juga terbukti mampu memberikan harapan kepada orang awam untuk meneruskan kehidupan normal selepas mengalami penyakit lumpuh. Penyataan ini disokong oleh dapatan kajian yang dilaksanakan oleh Fariza Fadzil et al. (2012) yang meninjau penerapan urut Melayu terhadap seorang pesakit wanita yang diserang strok selepas bersalin. Dapatan yang diperoleh pengkaji tersebut ialah wanita itu berjaya sembuh dan boleh melakukan kerja hariannya seperti sedia kala selepas menghadiri beberapa sesi urutan tradisional Melayu. Hal ini jelas membuktikan bahawa urutan tradisional Melayu sememangnya mampu menyembuhkan penyakit kronik seperti penyakit saraf sekali gus menafikan dakwaan orang awam terhadap seni urutan ini yang ketinggalan zaman dan tidak setanding dengan perubatan moden. Sandy Mark Luna (2015) mengatakan bahawa martabat pengamal urutan tradisional dan moden perlu diangkat ke tahap yang lebih tinggi memandangkan kerjaya ini mempunyai nilai komersial yang tinggi. Daripada laporan Sandy Mark Luna lagi, program MamaCare yang menawarkan khidmat urutan pascabersalin, pengamal MamaCare dapat mencecah pendapatan bulanan sebanyak RM33,000 bagi tiga bulan pertama. Hal ini jelas menunjukkan kerjaya sebagai tukang urut atau pengamal urutan tradisional mempunyai nilai komersial dan kelasnya tersendiri. 
Seni urutan tradisional Melayu sememangnya merupakan salah satu kearifan tempatan Melayu yang mencerminkan kemampuan, pengetahuan dan kepakaran yang dimiliki oleh tukang urut dalam menyelesaikan masalah penyakit. Hal ini terbukti dengan adanya manuskrip perubatan tradisional yang masih tersimpan, iaitu seperti Hikayat Nurul Lisan Menjawab Masalah, Bustan al-Salatin, Kitab Mujarrabat Melayu dan Kitab Ilmu Tabib (Mohd. Faizal Musa, 2014 \& Mohd. Qayyum Kamrudin et al., 2020). Selain itu, dapatan menunjukkan bahawa seni urutan tradisional Melayu ini sudah mempunyai identitinya yang unik tanpa memerlukan campuran pengaruh luar seperti urutan Siam, Swedish, urutan gaya Bali dan sebagainya. Konsep asas urutan tradisional Melayu tidak menggunakan pendekatan aromaterapi, tetapi hanya menggunakan minyak dan herba-herba sebagai tujuan perubatan.

Masyarakat melihat seni urutan tradisional Melayu ini sebagai seni warisan budaya asli Melayu sejak turun-temurun dan perlu dikekalkan identiti aslinya. Seni warisan ini memperlihatkan pengetahuan dan kearifan tempatan yang bersumberkan akumulasi pengetahuan dan pengalaman serta interaksi dengan budaya. Interaksi ini berterusan sejak dahulu lagi yang mempunyai hubung kaitnya antara fizikal, spiritual, persekitaran, psikologi dan kesihatan dalam perubatan Melayu. Hal ini juga menunjukkan perubatan dan urutan tradisional Melayu merupakan satu pengetahuan, kesenian, kebudayaan dalam bentuk kearifan tempatan yang bernilai tinggi serta mampu dikagumi oleh masyarakat lain.

Melihat kepada perkembangan dan kepesatan teknologi perubatan yang serba canggih kini, urutan tradisional Melayu masih lagi menjadi pilihan masyarakat dalam ikhtiar mereka untuk mendapatkan kelegaan dan mengurangkan kadar kesakitan terhadap apa-apa kecederaan sama ada kecederaan otot dan tisu ataupun kecederaan yang kritikal seperti patah tulang. Berpaksikan pandangan bahawa kerjaya tukang urut ini wajar dikomersialkan, sudah tiba masanya pihak kerajaan atau pihak yang bertanggungjawab menawarkan skim khas atau dana tertentu membantu tukang-tukang urut ini mengembangkan kerjayanya sekali gus membantu menambahkan pendapatan mereka seperti Skim Keselamatan Sosial Pekerjaan Sendiri di bawah peruntukan Akta Keselamatan Sosial Pekerjaan Sendiri 2017 melalui caruman Pertubuhan Kerja Sosial (PERKESO) dan melibatkan tukang urut itu sendiri dalam program Amanah Ikhtiar Malaysia (AIM) yang sebahagiannya adalah daripada pendekatan pembangunan komuniti yang menjalani proses transformasi hasil daripada pembangunan luar bandar (Nik Shahrizan Nik Mad et al., 2020).

Kepakaran dan kepandaian dalam seni urutan tradisional Melayu ini tidak seharusnya terkubur begitu sahaja. Sebagai pengamal urutan tradisional Melayu, tukang-tukang urut perlu memperturunkan ilmu dan kepakaran mereka kepada generasi muda supaya kekal relevan dan berterusan zaman-berzaman. Permintaan dan penerimaan masyarakat kini terhadap seni urutan tradisional Melayu ini wajar diberikan perhatian yang tuntas bagi menjamin masa depan kerjaya dan semestinya kemandirian seni warisan perubatan Melayu ini kekal relevan dan diwariskan. Dapatan ini selaras dengan Norizan Esa et al. (2018) yang menyatakan bahawa pewarisan ilmu urutan tradisional Melayu ini diperlukan setelah melihat kepada keupayaan tukang urut yang memberikan khidmat urutan secara tidak langsung mewujudkan kepercayaan dalam kalangan masyarakat yang mendapatkan urutan ini. 


\section{Kesimpulan}

Kajian isu kearifan tempatan dalam konteks seni urutan tradisional Melayu wajar dikembang dan dipergiat dengan lebih meluas. Seni urutan tradisional Melayu ini perlu dilihat dari sudut pandang yang lebih meluas. Mohd. Faizal Musa (2014) menyatakan bahawa tiada satu garis pemisahan yang jelas dan tegas antara perubatan moden dan tradisional. Pandangan ini menyifatkan urutan tradisional Melayu yang berasaskan kearifan tempatan menyediakan satu kaedah rawatan alternatif yang meyakinkan dan melegakan seseorang individu. Selain itu, urutan tradisional Melayu sebagai satu budaya perubatan yang berpaksikan kepada falsafah, pemikiran, kepakaran dan kemahiran seseorang tukang urut untuk diperturunkan kepada generasi muda. Pembudayaan ini sebenarnya ditunjangi dengan lingkungan alam yang begitu akrab dengan masyarakat di samping memanfaatkan pengalaman tukang urut, bomoh tulang dan bidan atau lebih tepat digelar sebagai pengamal perubatan tradisional Melayu. Masyarakat kini boleh menerima keberkesanan dalam urutan tradisional Melayu dan lebih bersikap terbuka untuk menerimanya. Namun demikian, kajian lanjutan tentang kearifan tempatan dalam urutan tradisional Melayu ini wajar dilakukan bagi mendapatkan maklumat dan data yang lebih menyeluruh. Hal ini bertujuan untuk memberikan pendedahan kepada masyarakat bahawa urutan tradisional Melayu ini masih mendapat tempat dalam kalangan masyarakat walaupun dunia sedang berada dalam Revolusi Industri 4.0 yang mementingkan teknologi berbanding dengan kudrat dan tenaga kerja manusia.

\section{Rujukan}

Abdul Ghani Ramli, Lutfi Jaafar, Shamsaini S. \& Fariza Fadzil, (2009). Traditional and complementary medicine practice guidelines on Malay massage (Second Edition). Traditional and Complementaty Medicine Division, Ministry of Health Malaysia.

Abdul Rani AA, Ab. Ghani RM, Shamsuddin S, Abdullah Z, Abdul Halim NH, Mustapha N \& Muhamad NA. (2015). Massage therapy for improving functional activity after stroke (protocol). Cochrane Database of Systematic Reviews. Issue 10, 1 - 11.

Aznim Ruhana Md. Yusup, (2017, Disember 5). Crafting a uniquely Malaysian massage. New Straits Time, pp. $1-7$.

Cambron, J. A., Dexheimer, J., Coe, P., \& Swenson, R. (2007). Side-effects of massage therapy: A cross-sectional study of 100 clients. The Journal of Alternative and Complementary Medicine. Vol. 13 (8), $793-796$.

Che Noriah Othman, Maryam Farooqui \& Roz Azinur Che Lamin. (2013). Malay traditional treatment (MTT) and general health quality (GHQ) among lower back pain (LBP) patients in Malaysia. Procedia-Social Behavioral Sciences. Vol. 101, 212 - 220.

Che Noriah Othman, Maryam Farooqui, Roz Azinur Che Lamina \& Norina Din. (2012). Malay traditional massage therapy (MTMT) seeking behaviours among Malays for their chronic diseases: Case study. Procedia-Social and Behavioral Sciences. Vol. 50, $591-601$. 
Ernst, E. (2003). The safety of massage therapy. Rheumatology. Vol. 42 (9), 1101 - 1109.

Fatin Farhana Japre. (2017). Kerjaya sebagai tukang urut. Harian Metro, Selasa 18 April. Kuala Lumpur.

Fariza Fazil, Haniza Mohd. Anuar, Suhaila Ismail, Norsuria Abd. Ghani \& Norlaili Ahmad. (2012). Urut Melayu, traditional Malay massage, as a complementary rehabilitative care in postportum stroke. Journal of Alternative and Complementary Medicine. Vol. 18 (4), 415 - 419.

Farooqui, M. M. A., Azmi, M., Knight, Shatar, A., Akmal, A., Boon, T. \& Aslam, M. (2012). Complementary therapies in clinical practice complementary and alternative medicine (CAM) use by Malaysian oncology patiens. Vol. 18, $114-120$.

Fuad Mohamed Berawi, (2017). Metodologi penyelidikan: Panduan menulis tesis. Sintok: Penerbit Universiti Utara Malaysia.

Haniza Mohd. Anuar, Fariza Fadzil, Shaheeda Mohd. Sallehuddin, Norlaili Ahmad \& Norsuria Abd. Ghani. (2010). A qualitative study on urut Melayu: The traditional Malay massage. Journal of Alternative and Complementary Medicine. Vol. 16 (11), 1201 - 1205.

Jamaluddin Mohd. Ali, Azizan Haji Baharuddin \& Wan Zailan Kamaruddin Wan Ali, (2016). Konsep tabii manusia menurut pandangan Jean-Jacques Rousseau: Suatu analisis dari sudut moral. Jurnal Peradaban. Jilid 9, 51 - 72.

Kamus Dewan Perdana. (2020). Kuala Lumpur: Dewan Bahasa dan Pustaka.

Krejcie, R. V., \& Morgan, D. W. (1970). Determining sample size for research activities. Educational And Psychological Measurement. Vol. 30 (3), 607 - 610.

McGuirk, P. M. \& O’Neill, P. (2016). Using questionnaires in qualitative human geography. In I. Hay (Eds.), Qualitative Research Methods in Human Geography (pp. 246-273). Don Mills, Canada: Oxford University Press.

Mohd. Anuar Ramli, Muhammad Ikhlas Rosele, Mohd. Aizat Jamaluddin \& Mohd. Akmal Sidik. (2016). Sumbangan ulama Melayu klasik dalam pembinaan kearifan tempatan di alam Melayu. Jurnal Pengajian Melayu. Jilid 27 (1), 178-190.

Mohd. Anuar Ramli, Muhammad Yusri Yusof, Mohd. Zahirwan Halim, Saiful Islam \& Muhammad Ali Mukhtar. (2018). Kearifan tempatan dalam hukum Islam di alam Melayu. Kertas kerja Seminar Hukum Islam Semasa IX. Kertas kerja yang tidak diterbitkan.

Mohd. Faizal Musa. (2014). Beberapa nota kearifan Melayu tentang sakit tuan: Satu pengenalan. International Journal of the Malay World and Civilisation. Jilid 2 (3), 87 - 97.

Mohd. Qayyum Kamrudin, Mohd. Nasir Ripin, Zulkiflee Haron \& Norhissam Mustafa. (2019). Tasawur perubatan Melayu berdasarkan kitab perubatan Melayu. International Journal of Islamic and Civilazational Studies. Vol. 3 (2), 39 - 54.

Mohd. Zahirwan Halim Zainal Abidin, Muhammad Yusri Yusof, Paiz Hassan, Hamdi Rahman Mohd. Yaacob, Shahril Nizam Zulkipli \& Ab. Munir Md. Noh. (2014). Pengaruh Islam dalam perkembangan intelektual di Alam Melayu. Jurnal Pengajian Melayu/Journal of 
Malay Studies (JOMAS). Jilid 25, $102-116$.

Mungmachon, R. (2012). Knowledge and local wisdom: Community treasure. International Journal of Humanities and Social Science. Vol. 2 (13), $174-181$.

Munn, P., \& Drever, E. (1990). Using Questionnaires in Small-Scale Research. A Teachers' Guide. Scottish Council for Research in Education, 15 St. John Street, Edinburgh, EH8 8JR, Scotland, United Kingdom.

Nik Shahrizan Nik Mad, Marzudi Md. Yunus \& Muhammad Shamsinor Abdul Azziz. (2020). Kesejahteraan subjektif: Halangan dan cabaran peserta program mikro kredit Amanah Ikhtiar Malaysia di cawangan Kepong, Wilayah Selangor dan Kuala Lumpur Tengah. Jurnal Pengajian Melayu. Jilid 31, 20 - 35.

Newell, R., \& Burnard, P. (2010). Research for evidence-based practice in healthcare. Chichester, United Kingdom: John Wiley \& Sons.

Norizan Esa, Salasiah Che Lah \& Sakiinah Mahamad Hakimi. (2018). Knowledge transfer and management among Malay traditional massage practitioners in the north of Malaysia. SHS Web of Conferences. Vol. 45, $1-5$.

Rahimin Affandi Abd. Rahim, Ruzman Md. Nor, Nor Hayati Md. Dahlal \& Norafifah Abd. Hamid. (2013). Islam dan kearifan tempatan di alam Melayu: Analisis kritikal. JATI. Jilid 18, 223 -245 .

Reissland, N., \& Burghart, R. (1987). The role of massage in south Asia: Child health and development. Social Ccience \& Medicine. Vol. 25 (3), 231 - 239.

Reja, U., Manfreda, K. L., Hlebec, V., \& Vehovar, V. (2003). Open-ended vs. close-ended questions in web questionnaires. Developments in applied statistics. Vol. 19 (1), 159-177.

Rosliza Abdul Manaf \& Suriani Ismail. (2017). The use of traditional Malay massage and traditional Malay herbs in Malaysia: A review. International Journal of Public Health and Clinical Science. Vol. 4 (5), $24-37$.

Rosnani Ripin. (2016). Amalan urut Melayu patuh syariah. Kertas Kerja Persidangan dan Perbincangan Fiqh Antarabangsa 22 - 23 November 2016. Kertas kerja yang tidak diterbitkan.

Rousseau, Jean-Jacques. (1967). The social contract and discourse on the origin of in-equality. New York: Washington Square Press.

Sesilia Seli \& Mohamad Mokhtar Abu Hassan. (2016). Makna simbol-simbol fizikal daripada kearifan tempatan dalam cerita Ne'Baruaking Kulup sastera lisan Dayak Kanayatn. Jurnal Pengajian Melayu/Journal of Malay Studies (JOMAS). Jilid 27, 70 - 105.

Suswandari. (2017). Kearifan tempatan etnik Betawi. Jogjakarta, Indonesia: Pustaka Pelajar.

Syamsul Azizul Marinsah, Mohd. Nur Hidayat Hasbollah Hajimin \& Mohd. Anuar Ramli. (2019). Unsur kearifan tempatan dalam adat kematian masyarakat Bajau di Sabah: Analisis dari perspektif hukum Islam. Jurnal Pusat Penataran Ilmu dan Bahasa. Jil. 29, 51 - 69. 
Wan Farzana Fasya, Vivin Dianta Devita, Nurul Ain, Noor Amanina, Suriani Ismail \& Rosliza A.M. (2017). The use traditional Malay massage and traditional Malay herbs in Malaysia: A review. Interntional Journal of Public Health and Clinical Sciences. Vol. 4 (5), 24 - 37.

Wan Noor Hayati. (2015). Tukang urut warga asing raih RM8,000 sebulan. BH Online, 20 Oktober, Kuala Lumpur. 